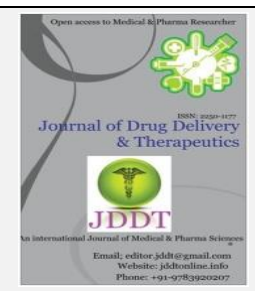

Research Article

Open - Access

,

Research Article

\title{
Screening of Phytochemicals and Antioxidant Potential of Leaves Extract of Litsea glutinosa
}

\author{
Brijesh K. Sharma*, Kavita R. Loksh, Dr. Alok Pal Jain, \\ Sarvepalli Radhakrishnan University, NH-12 Hoshangabad Road, Misrod, Bhopal-462026 (M.P.) India
}

\begin{abstract}
Litsea glutinosa (Lour) leaves are deliberated as worthy traditional medicine. The aim of this study was to screen the phytochemicals, to evaluate the total flavonoid contents as well as antioxidant activity of various extract of Litsea glutinosa (Lour). The phytochemical analysis of each solvent extract was also carried out. Total flavonoid content was determined by aluminium chloride colorimetric assay. Antioxidant activity was determined using 2, 2-diphenyl-1-picrylhydrazyl (DPPH), Ferric reducing ability of plasma (FRAP) and Hydrogen Peroxide ( ${ }_{2} \mathrm{O}_{2}$ ) free radical scavenger methods. Phytochemical screening of various extract revealed the presence of Alkaloids, Flavonoids, Diterpenes, Proteins, Carbohydrate and Saponins. The total flavonoid content was found 1.89, 5.01 and $3.16 \mathrm{mg} / 100 \mathrm{mg}$ of dry weight of pet ether, ethanol and aqueous extract respectively, expressed as Quercetin equivalents. Antioxidant activity was performed using three methods DPPH, Ferric reducing ability of plasma (FRAP) assay and Hydrogen Peroxide scavenging activity. Our current results emerged that Litsea glutinosa (Lour) act as an antioxidant agent due to its free radical scavenging. So, the plant may be further pursued to find out for its pharmacological active natural products.
\end{abstract}

Keywords: Litsea glutinosa (Lour), Qualitative, Quantitative phytochemical, Antioxidant activity.

Article Info: Received 09 July 2019; Review Completed 11 Aug 2019; Accepted 18 Aug 2019; Available online 25 August 2019

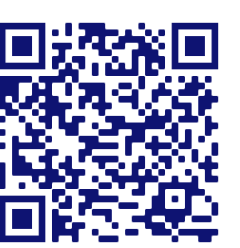

\section{Cite this article as:}

Sharma BK, Loksh KR, Jain AP, Screening of Phytochemicals and Antioxidant Potential of Leaves Extract of Litsea glutinosa, Journal of Drug Delivery and Therapeutics. 2019; 9(4-s):1214-1217～DOI: http://dx.doi.org/10.22270/jddt.v9i4-s.3939

*Address for Correspondence:

Brijesh K. Sharma, Sarvepalli Radhakrishnan University, NH-12 Hoshangabad Road, Misrod, Bhopal-462026 (M.P.) India

\section{INTRODUCTION}

Since very old times, herbal medications have been used for relief of symptoms of disease ${ }^{1}$. Despite the great advances observed in modern medicine in recent decades, plants still make an important contribution to health care. Much interest, in medicinal plants however, emanates from their long use in folk medicines as well as their prophylactic properties, especially in developing countries. Large number of medicinal plants has been investigated for their antioxidant properties. Natural antioxidants either in the form of raw extracts or their chemical constituents are very effective to prevent the destructive processes caused by oxidative stress ${ }^{2}$. Al- though the toxicity profile of most medicinal plants have not been thoroughly evaluated, it is generally accepted that medicines derived from plant products are safer than their synthetic counterparts ${ }^{3-4}$. In recent years, consumption of vegetables and fruits in the average diet has been highlighted for its contribution towards lowering the risks of several life-threatening diseases such as coronary heart disease, stroke, pulmonary disease, and different types of cancer ${ }^{5-14}$. The benefits are due to the presence of polyphenols, Flavonoids and vitamins ${ }^{15-17}$ of these phytochemicals, polyphenols are largely recognized as anti-inflammatory, antiviral, antimicrobial, and antioxidant agents.

Litsea glutinosa (Lour.) C. B. Rob., is an aromatic medicinal tree belongs to the family Lauraceae and rarely distributed in the Western Ghats. It is a medicinal plant of immense pharmaceutical value. The species is critically endangered due to its indiscriminate collection as raw material for pharmaceutical industry, where it is used for manufacturing drugs for pain, arousing sexual power and in treatment of diarrhea and dysentery etc ${ }^{18-19}$. The search for novel natural antioxidants of plant origin has ever since increased. It is not known which constituents of plant are associated in reducing the risk of chronic diseases, but antioxidants appear to play a major role in the protective effect of plant medicine. The present study was designed to investigate the total flavonoids Content (TFC) and to evaluate the in vitro antioxidant activities of the various extract of Litsea glutinosa (Lour). 


\section{MATERIAL AND METHOD}

\section{Chemicals and equipment}

Methanol, 1, 1-diphenyl-2- picrylhydrazyl (DPPH), aluminium chloride, ascorbic acid, quercetin, ferric chloride, potassium ferricyanide, sodium hydroxide and sodium nitrite used in this study. All the chemicals used in this study were obtained from Hi Media Laboratories Pvt. Ltd. (Mumbai, India), Sigma-Aldrich Chemical Co. (Milwaukee, WI, USA), SD Fine-Chem. Ltd. (Mumbai, India) and SRL Pvt. Ltd. (Mumbai, India). All the chemicals and solvent used in this study were of analytical grade. Labindia 3000+ UV/Visible spectrophotometer was used to measure the absorbance.

\section{Collection of Plant material}

Fresh leaves of Litsea glutinosa (Lour) were collected and were authenticated by Dr. Jaswinder Mehta, HOD, Department of Botany, Career College, Bhopal (M.P.).

\section{Preparation of Extracts}

120 gram of powdered leaves of Litsea glutinosa (Lour) were exhaustively extracted with different solvent (Pet ether, ethanol and aqueous) by maceration method. The extract was evaporated above their boiling points. Finally, the percentage yields were calculated of the dried extracts $20-22$.

\section{Calculation of percentage yield}

The percentage yield of yield of each extract was calculated by using formula:

$$
\text { Percentage yield }=\frac{\text { Weight of extract }}{\text { Weight of poedered drug taken }}
$$

\section{Phytochemical analysis}

All the test samples were subjected to phytochemical analysis to find out the presence of chemical constituents according to Trease and Evans, Harborne and Sofowora ${ }^{23-25 .}$

\section{Quantitative Determination of Phytochemical (Total flavonoids Content)}

The total flavonoid content was determined using the method of Ordonez et al., ${ }^{26} .1 \mathrm{ml}$ of $2 \% \mathrm{AlCl} 3$ solution was added to $3 \mathrm{ml}$ of extract or standard and allowed to stand for $15 \mathrm{~min}$ at room temperature; the absorbance of the reaction mixture was measured at $420 \mathrm{~nm}$ using UV/visible spectrophotometer. The content of flavonoids was calculated using standard graph of quercetin and the results were expressed as quercetin equivalent (mg/100mg).

\section{In-vitro antioxidant activity of Leaves of Litsea glutinosa (Lour) using different methods}

\section{DPPH method}

DPPH scavenging activity was measured by the spectrophotometer ${ }^{27}$. Stock solution $(6 \mathrm{mg}$ in $100 \mathrm{ml}$ methanol) was prepared such that $1.5 \mathrm{ml}$ of it in $1.5 \mathrm{ml}$ of methanol gave an initial absorbance. Decrease in the absorbance in presence of sample extract at different concentration $(10-100 \mu \mathrm{g} / \mathrm{ml})$ was noted after 15 minutes. $1.5 \mathrm{ml}$ of DPPH solution was taken and volume made till $3 \mathrm{ml}$ with methanol, absorbance was taken immediately at 517 $\mathrm{nm}$ for control reading. $1.5 \mathrm{ml}$ of DPPH and $1.5 \mathrm{ml}$ of the test sample of different concentration were put in a series of volumetric flasks and final volume was adjusted to $3 \mathrm{ml}$ with methanol. Three test samples were taken and each processed similarly. Finally the mean was taken. Final decrease in absorbance was noted of DPPH with the sample at different concentration after 15 minutes at $517 \mathrm{~nm}$.

\section{Ferric reducing ability of plasma (FRAP) assay}

The ferric ion reducing power of extracts was determined by measuring the absorbance of chromophore 28 . Different concentrations of extracts or standard, vitamin C (1 mL, 10$100 \mu \mathrm{g} / \mathrm{mL})$ were mixed with phosphate buffer $(2.5 \mathrm{~mL}, 0.2$ $\mathrm{M}, \mathrm{pH} 6.6)$, potassium ferric cyanide $(2.5 \mathrm{~mL}, 1 \% \mathrm{w} / \mathrm{v})$ and incubated at $50 \pm 2^{\circ} \mathrm{C}$ for $20 \mathrm{~min}$. Trichloroacetic acid $(2.5$ $\mathrm{mL}, 10 \% \mathrm{w} / \mathrm{v}$ ) was added to the mixture and centrifuged at $3000 \mathrm{rpm}$ for $10 \mathrm{~min}$. The upper layer of the solution $(2.5 \mathrm{~mL})$ was separated and mixed with $2.5 \mathrm{~mL}$ of distilled water and ferric chloride $(0.5 \mathrm{~mL}, 0.1 \% \mathrm{w} / \mathrm{v})$. Then, the absorbance was measured at $\lambda_{\max } 700 \mathrm{~nm}$ using UV-Vis spectrophotometer (Labindia 3000 plus, India).

\section{Hydrogen Peroxide scavenging activity}

In-vitro antioxidant activity of the different extracts using hydrogen peroxide was performed as Czochra and Widensk proposed $^{29}$. Added $2 \mathrm{ml}$ hydrogen peroxide ( $43 \mathrm{~mol}$ ) and 1.0 $\mathrm{ml}$ ethanol sample $[20-100 \mu \mathrm{l}$ different extracts $(4 \mathrm{mg} / \mathrm{ml})$ ethanol] accompanied by $2.4 \mathrm{ml} 0.1 \mathrm{M}$ phosphate buffer $(\mathrm{pH}$ 7.4). The resulting solution was maintained for 10 minutes and the absorbance at $230 \mathrm{~nm}$ was recorded. Three times all measurements were repeated. Without adding hydrogen peroxide, blank was ready and control was prepared without sample. It was used as a conventional compound with ascorbic acid. Free radical hydrogen peroxide scavenging activity (percent) has been calculated.

Calculation of \%Reduction $\frac{\text { Control Absorbance }- \text { Test absorbance }}{\text { Control Absorbance }}$ X100

\section{RESULTS AND DISCUSSION}

The percentage yields of various extract obtained from Litsea glutinosa (Lour) are depicted in the Table 1. The maximum percentage yield was found in ethanol extract as compared to pet. ether and aqueous extract. Preliminary phytochemical studies of the extract were done according to standard methods. Phytochemical analysis revealed the presence of various bioactive constituents shown in Table 2. Data for total flavonoid content has been summarized in Table 3. Phenolic compounds of plants fall into several categories; chief among these are the flavonoids which have potent antioxidant activities. Flavonoids are naturally occurring in plants and are thought to have positive effects on human health.

Results for the free radical scavenging activity of ethanolic extract of Litsea glutinosa (Lour) are shown in Table 4. The extract showed radical scavenging effect in DPPH assay. The half inhibition concentration $\left(\mathrm{IC}_{50}\right.$ ) for free radicals achieved by the extract was $82.471 \mu \mathrm{g} / \mathrm{ml}$ which is statistically significant compared that $\left(\mathrm{IC}_{50} 17.681 \mu \mathrm{g} / \mathrm{ml}\right.$ ) of reference antioxidative agent ascorbic acid. The extract showed significant reducing power activities as compared to ascorbic acid and proportionally increased with the increasing concentration of the extract, which is shown in Table 5. The scavenging ability of ethanolic extract of Litsea glutinosa (Lour) on hydrogen peroxide was shown in Table 6 and compared with Ascorbic acid as standards. The Litsea glutinosa extract were capable of scavenging hydrogen peroxide in an amount dependent manner.

Table No. 1: \% Yield of Leaves of Litsea glutinosa (Lour)

\begin{tabular}{|c|c|c|}
\hline \multirow{2}{*}{ S. No. } & \multirow{2}{*}{ Extracts } & \% Yield (W/W) \\
\cline { 3 - 3 } & & Litsea glutinosa (Lour) \\
\hline 1. & Pet. ether & 1.37 \\
\hline 2. & Ethanol & 2.40 \\
\hline 3. & Aqueous & 1.57 \\
\hline
\end{tabular}


Table No. 2: Result of Phytochemical Screening of Leaves of Litsea glutinosa (Lour)

\begin{tabular}{|c|c|c|c|c|}
\hline S. No. & Constituents & Pet ether extract & Ethanol extract & Aqueous extract \\
\hline 1. & $\begin{array}{c}\text { Alkaloids } \\
\text { Hager's Test: }\end{array}$ & +ve & + ve & +ve \\
\hline 2. & $\begin{array}{l}\text { Glycosides } \\
\text { Legal's Test: }\end{array}$ & -ve & -ve & -ve \\
\hline 3. & $\begin{array}{c}\text { Flavonoids } \\
\text { Lead acetate Test: }\end{array}$ & +ve & $+\mathrm{ve}$ & $+\mathrm{ve}$ \\
\hline 4. & $\begin{array}{c}\text { Diterpenes } \\
\text { Copper acetate Test: }\end{array}$ & $+v e$ & +ve & +ve \\
\hline 5. & $\begin{array}{c}\text { Phenol } \\
\text { Ferric Chloride Test: }\end{array}$ & -ve & -ve & -ve \\
\hline 6. & $\begin{array}{c}\text { Proteins } \\
\text { Xanthoproteic Test: }\end{array}$ & -ve & +ve & +ve \\
\hline 7. & $\begin{array}{l}\text { Carbohydrate } \\
\text { Fehling's Test: }\end{array}$ & -ve & -ve & $+\mathrm{ve}$ \\
\hline 8. & $\begin{array}{c}\text { Saponins } \\
\text { Froth Test: }\end{array}$ & -ve & -ve & $+\mathrm{ve}$ \\
\hline
\end{tabular}

Table No. 3: Estimation of total flavonoids content of Litsea glutinosa (Lour) extract

\begin{tabular}{|c|c|c|}
\hline S. No. & Extracts & $\begin{array}{c}\text { Total flavonoids content } \\
\text { (mg/ 100 mg of dried extract) }\end{array}$ \\
\hline $\mathbf{1}$ & Pet ether & 1.89 \\
\hline $\mathbf{2}$ & Ethanol & 5.01 \\
\hline $\mathbf{3}$ & Aqueous & 3.16 \\
\hline
\end{tabular}

Results of antioxidant activity using different model

Results of antioxidant activity using DPPH method

Table No. 4: \% Inhibition of ascorbic acid and ethanolic extract of Litsea glutinosa (Lour) using DPPH method

\begin{tabular}{|c|c|c|c|}
\hline S. No. & $\begin{array}{c}\text { Concentration } \\
(\boldsymbol{\mu g} / \mathbf{m l})\end{array}$ & Ascorbic acid & Litsea glutinosa (Lour) extract \\
\cline { 2 - 4 } & 10 & 44.65 & 41.69 \\
\hline 1 & 20 & 48.62 & 46.1 \\
\hline 2 & 40 & 65.34 & 46.77 \\
\hline 3 & 60 & 69.65 & 47.79 \\
\hline 4 & 80 & 77.41 & 50.50 \\
\hline 5 & 100 & 84.13 & 50.84 \\
\hline 6 & & 17.681 & 82.471 \\
\hline
\end{tabular}

Results of antioxidant activity using Ferric reducing ability of plasma (FRAP) assay

Table No. 5: Results of antioxidant activity using Ferric reducing ability of plasma (FRAP) assay

\begin{tabular}{|c|c|c|c|}
\hline & & \multicolumn{2}{|c|}{ Absorbance } \\
\hline S. No. & Concentration $(\boldsymbol{\mu g} / \mathbf{m l})$ & (Ascorbic acid) & Litsea glutinosa (Lour) extract \\
\hline $\mathbf{1}$ & $\mathbf{0}$ & 0 & 0 \\
\hline $\mathbf{2}$ & $\mathbf{1 0}$ & 0.345 & 0.089 \\
\hline $\mathbf{3}$ & $\mathbf{2 0}$ & 0.489 & 0.125 \\
\hline $\mathbf{4}$ & $\mathbf{4 0}$ & 0.596 & 0.225 \\
\hline $\mathbf{5}$ & $\mathbf{6 0}$ & 0.662 & 0.365 \\
\hline $\mathbf{6}$ & $\mathbf{8 0}$ & 0.895 & 0.389 \\
\hline $\mathbf{7}$ & $\mathbf{1 0 0}$ & 0.896 & 0.425 \\
\hline $\mathbf{8}$ & $\mathbf{1 2 0}$ & 0.892 & 0.521 \\
\hline $\mathbf{9}$ & $\mathbf{1 5 0}$ & 0.891 & 0.532 \\
\hline $\mathbf{1 0}$ & $\mathbf{2 0 0}$ & 0.896 & 0.533 \\
\hline
\end{tabular}


Results of antioxidant activity using $\mathrm{H}_{2} \mathrm{O}_{2}$ method

Table No. 6: \% Inhibition of ascorbic acid and ethanolic extract of Litsea glutinosa (Lour) using $\mathrm{H}_{2} \mathrm{O}_{2}$ method

\begin{tabular}{|c|c|c|c|}
\hline \multirow{2}{*}{ S. No. } & $\begin{array}{c}\text { Concentration } \\
(\boldsymbol{\mu g} / \mathbf{m l})\end{array}$ & Ascorbic acid & \%itsea glutinosa (Lour) extract \\
\cline { 3 - 4 } & 20 & 42.872 & 31.88 \\
\hline 1 & 40 & 52.192 & 38.24 \\
\hline 3 & 60 & 60.416 & 43.55 \\
\hline 4 & 80 & 65.789 & 47.63 \\
\hline 5 & 100 & 68.750 & 50.89 \\
\hline
\end{tabular}

\section{CONCLUSION}

The present study indicated that Litsea glutinosa (Lour) contains considerable amount of phytoconstituents especially total flavonoids and exhibited good antioxidant activity by effectively scavenging various free radicals. The extract showed radical scavenging effect in DPPH assay. The half inhibition concentration ( $\mathrm{IC}_{50}$ ) for free radicals achieved by the extract was $82.471 \mu \mathrm{g} / \mathrm{ml}$ which is statistically significant compared that $\left(\mathrm{IC}_{50} 17.681 \mu \mathrm{g} / \mathrm{ml}\right.$ ) of reference antioxidative agent ascorbic acid. The antioxidant activities might be due to the synergistic actions of bioactive compounds present in them. However, it is still unclear which components are playing vital roles for this activity. Therefore, further studies are still needed to elucidate mechanistic way how the plant contributes to this property.

\section{REFERENCES}

1. Maqsood S, Singh P, Samoon MH, Balange AK: Effect of dietary chitosan on non-specific immune response and growth of Cyprinus carpio challenged with Aeromonas hydrophila. Inter Aqua Res 2010, 2:77-85.

2. Zengin G, Cakmak YS, Guler GO, Aktumsek A: Antioxidant properties of methanolic extract and fatty acid composition of Centaurea urvillei DC. subsp. hayekiana Wagenitz. Rec Nat Prod 2011, 5:123-132.

3. Vongtau HO, Abbah J, Chindo BA, Mosugu O, Salawu AO, Kwanashie HO, Gamaniel KS: Central inhibitory effects of the methanol extract of Neorautanenia mitis root in rats and mice. J Pharm Biol 2005, 43:113-120.

4. Oluyemi KA, Okwuonu UC, Baxter DG, Oyesola TO: Toxic effects of methanolic exract of Aspilia africana leaf on the estrous cycle and uterine tissues of Wistar rats. Int J Morphol 2007, 25:609-614.

5. Frydoonfar HR, McGrath DR, and A. D. Spigelman, "The variable effect on proliferation of a colon cancer cell line by the citrus fruit flavonoid Naringenin," Colorectal Disease, vol. 5, no. 2, pp. 149-152, 2003.

6. Hakimuddin F, Paliyath G, and Meckling $\mathrm{K}$, "Selective cytotoxicity of a red grape wine flavonoid fraction against MCF-7 cells," Breast Cancer Research and Treatment, vol. 85, no. 1, pp. 65-79, 2004.

7. Joshipura KJ, Hu FB, Manson JE et al., "The effect of fruit and vegetable intake on risk for coronary heart disease," Annals of Internal Medicine, vol. 134, no. 12, pp. 1106-1114, 2001.

8. Khanzode SS, Muddeshwar MG, Khanzode SD, and Dakhale GN, "Antioxidant enzymes and lipid peroxidation in different stages of breast cancer," Free Radical Research, vol. 38, no. 1, pp. 81-85, 2004.

9. Larsson SC, Holmberg L, and Wolk A, "Fruit and vegetable consumption in relation to ovarian cancer incidence: the Swedish mammography cohort," The British Journal of Cancer, vol. 90, no. 11, pp. 2167-2170, 2004.

10. Liu Y, Sobue T, Otani T, and Tsugane S, "Vegetables, fruit consumption and risk of lung cancer among middle-aged
Japanese men and women: JPHC study," Cancer Causes and Control, vol. 15, no. 4, pp. 349-357, 2004.

11. McCullough ML, Robertson AS, A. Chao et al., "A prospective study of whole grains, fruits, vegetables and colon cancer risk," Cancer Causes and Control, vol. 14, no. 10, pp. 959-970, 2003.

12. Polidori MC, "Antioxidant micronutrients in the prevention of age-related diseases," Journal of Postgraduate Medicine, vol. 49, no. 3, pp. 229-235, 2003.

13. Reddy KS, Katan MB, "Diet, nutrition and the prevention of hypertension and cardiovascular diseases," Public Health Nutrition, vol. 7, no. 1, pp. 167-186, 2004.

14. Voko Z, Hollander M, Hofman A, P. J. Koudstaal, and M. M. B. Breteler, "Dietary antioxidants and the risk of ischemic stroke: the Rotterdam study," Neurology, vol. 61, no. 9, pp. 12731275, 2003.

15. Steinmetz KA, Potter JD, "Vegetables, fruit, and cancer prevention: a review," Journal of the American Dietetic Association, vol. 96, no. 10, pp. 1027-1039, 1996.

16. Scalbert A, Williamson G, "Dietary intake and bioavailability of polyphenols," Journal of Nutrition, vol. 130, no. 8, pp. 20732085, 2000.

17. Willett WC, "Balancing life-style and genomics research for disease prevention," Science, vol. 296, no. 5568, pp. 695-698, 2002.

18. Kritikar K, Basu BD (1981). Indian Medicinal Plant, Periodic Book Agency, Delhi, India, III. pp. 2158-2160

19. P. Devi, R. Meera, "Study of antioxidant, anti inflammatoryand wound healing activity of extracts of Litsea glutinosa",Journal of Pharmaceutical Sciences and Research, Vol.2, Issue.2, pp 155-163, 2010.

20. Khandelwal KR. Ed. Practical Pharmacognosy Technique and Experiments, 23 ${ }^{\text {rd }}$ Edn: 2005; 15.

21. Kokate CK. Ed. Practical Pharmacognosy, $4^{\text {th }}$ Edn., Vallabh Prakashan: 1994; 112:120.

22. Mukherjee PK. Quality Control of Herbal Drugs, 2nd Edition, Business Horizons, 2007; 2-14.

23. Trease GE and Evans WC (1989). Pharmacognsy. 11th edition. Brailliar Tiridel Can. Macmillian Publishers, pp: 257.

24. Harborne JB (1973). Phytochemical Methods. Chapman and Hall limited, London. pp: 49-188

25. Sofowora AE (1993). Medicinal Plants and Traditional Medicine in Africa. 2nd edition. Spectrum Books, Ibadan, Nigeria. pp: 289.

26. Ordonez AAL, Gomez JD, Vattuone MA, Isla MI: Antioxidant activity of Sechium edule (Jacq.) Swart extracts. Food Chem. 2006, 97: 431-437.

27. Olufunmiso, Olajuyigbe, O. and Afolayan, Anthony, J. (2011). phenolic Content and antioxidant property of the bark extract of Ziziphus mucronata wild. Subsp. Mucronata wild, BMC, Complementary and alternative medicine. 11: 130.

28. Amarowicz R, Estrella I, Hernandez T, Robredo S, Agnieszka T, Kosinska A and Pegg RB. 2010. Free radical-scavenging capacity, antioxidant activity, and phenolic composition of green lentil (Lens culinaris). Food Chem. 121: 705-711.

29. Czochra MP, Widensk AJ. Spectrophotometric determination of $\mathrm{H}_{2} \mathrm{O}_{2}$ activity. Anal Chem Acta. 2002; 452:177-84. 